Article

\title{
Organizations towards the Evaluation of Environmental Management Tools ISO 14001 and EMAS
}

\author{
Agnieszka Ociepa-Kubicka ${ }^{1}$, Iwona Deska ${ }^{2, *(\mathbb{D})}$ and Ewa Ociepa ${ }^{2}$ \\ 1 Faculty of Management, Czestochowa University of Technology, Armii Krajowej 19 B, \\ 42-218 Częstochowa, Poland; a.ociepa-kubicka@pcz.pl \\ 2 Faculty of Infrastructure and Environment, Czestochowa University of Technology, Brzeźnicka 60 A, \\ 42-215 Częstochowa, Poland; ewa.ociepa@pcz.pl \\ * Correspondence: iwona.deska@pcz.pl; Tel.: +48-343-250-917
}

Citation: Ociepa-Kubicka, A.; Deska, I.; Ociepa, E. Organizations towards the Evaluation of Environmental Management Tools ISO 14001 and EMAS. Energies 2021, 14, 4870. https://doi.org/10.3390/ en14164870

Academic Editor: Seung-Gu Shin

Received: 17 July 2021

Accepted: 4 August 2021

Published: 10 August 2021

Publisher's Note: MDPI stays neutral with regard to jurisdictional claims in published maps and institutional affiliations.

Copyright: (c) 2021 by the authors. Licensee MDPI, Basel, Switzerland. This article is an open access article distributed under the terms and conditions of the Creative Commons Attribution (CC BY) license (https:// creativecommons.org/licenses/by/ $4.0 /)$.

\begin{abstract}
The purpose of this article is to analyze and compare the benefits of and barriers to the implementation of Environmental Management Systems (EMS) - International Standard ISO 14001 and Eco-Management and Audit Scheme (EMAS) — by organizations. This paper attempts to answer the following research questions: 1. Does the implementation of either ISO 14001 or EMAS bring the same benefits and barriers to organizations? 2. Does the system functioning duration in the company influence internal and external benefits resulting from EMS implementation? 3. Are economic aspects of EMS adoption as important for entrepreneurs as the ecological aspects? This topic is important due to the large disproportions appearing in recent years between the number of companies registered in ISO 14001 and in EMAS, and due to relatively frequent cases of non-renewal of EMAS certifications in recent years. It is crucial because each EMS certified institution has implemented procedures which contribute to better protection of the natural environment. The study was conducted in the form of a survey; questions and answers were specified based on the literature review and the authors' research. Results indicate that the knowledge-based and organizational problems, as well as the time invested in preparing the documentation, are much more significant than financial problems associated with EMS implementation. Even organizations that previously introduced ISO 14001 still have difficulties with EMAS implementation. The perception of benefits resulting from EMS introduction is related to the system functioning duration in the company. The analysis shows that it is necessary to strengthen economic incentives in order to enable the widest possible dissemination of EMS among companies. Research results can contribute to further simplification and increases in EMS implementation, which may lead to more sustainable development and climate change mitigation, inter alia, due to the improvement in energy efficiency, increased use of renewable energy, and reduction of greenhouse gas emissions.
\end{abstract}

Keywords: environmental management system; eco-management and audit scheme; EMAS; ISO 14001; organization; management; environmental protection; sustainable development

\section{Introduction}

The development of businesses must go hand in hand with caring about the natural environment. Companies around the world are increasingly beginning to implement a corporate social responsibility (CSR) strategy, defined as the "responsibility of companies for their impact on society" [1]. One of the main tasks of CSR is to manage the company's activities in a sustainable and environmentally friendly way [2]. Many analyses indicate that the promotion of environmental management systems (EMS) and their benefits is very important [3], in particular since their implementation in companies has an impact on the quality of products, processes, and green supply chain management [4]. HerasSaizarbitoria et al., in an article published in 2016 [5], analyze the internal and external sources of motivation which lead companies to adopt EMS. They have concluded that 
EMS certified companies belonging to the group or cluster with more intensive sources of motivation experience higher outcomes from the adoption of environmental management systems. The technological innovations and solutions may lead to the reduction of negative impacts of manufacturing plants on the natural environment [6]. The implementation of environmental protection measures can support sustainable development and thus provide economic, ecological, and social benefits for the society (i.e., for authorities, scientists, businesses, etc. [7]).

The environmental management strategy in organizations is based on elements such as waste prevention, the reduction of waste sources [8], the reduction of pollution and waste management [9], as well as sustainable energy management [10], use of renewable energy sources [11], reduction of greenhouse gas (e.g., $\mathrm{CO}_{2}$ ) emissions [12], and water resources protection [13] (e.g., reduction of water losses in water supply [14]), etc. Companies should take advantage of an economy operating with higher rates of technological development, higher energy efficiency, as well as improved optimized materials [15]. Examples of global systems used to help companies to minimize their environmental impact are, among others, two environmental management systems: the International Standard ISO 14001, and the Eco-Management and Audit Scheme (EMAS) [16].

EMAS is an environmental management system alternative to ISO 14001 and it is an extension of this international standard. The standard ISO 14001 [17] was introduced by the International Organization for Standardization. The EMAS scheme, on the other hand, is an instrument created by the European Commission and issued as Regulation (EC) No 1221/2009 [18] of the European Parliament and of the Council of 25 November 2009, as amended by the Commission Regulation (EU) 2017/1505 of 28 August 2017 [19]. The main assumption of both systems is to reduce the negative impact on the natural environment by taking action beyond the existing environmental legislation, and planning for continuous improvement of environmental activities. It should be emphasized that both ISO 14001 and EMAS certified companies carry out the energy management practices, even though they have not implemented the official Energy Management Systems (EnMSs), e.g., based on an International Standard ISO 50001 [10]. For example, the international standard ISO 14001:2015 recommends the reduction of energy consumption or replacement of non-renewable energy sources with clean energy to minimize the emissions and reduce environmental impact [10]. One of the most important benefits resulting from the use of sustainable resources and renewable energy sources is the climate change mitigation and adaptation. It should be stressed that the implementation of ISO 14001 can lay the foundations for many pro-environment actions, e.g., the reduction of emissions of particular matter (PM), $\mathrm{CO}_{2}$ and $\mathrm{SO}_{2}$, as well as reduced energy consumption and less heat losses [20]. Similarly, EMAS (especially its third update) emphasizes the energy management aspects and proposes the indicators of energy efficacy for diversified economic sectors [10]. EMAS regulation leads enterprises and organizations to reduce the consumption of energy and raw materials, as well as to optimize the waste production and respect the law limits with use of environmental indicators [21]. Novelli et al., in their article published in 2020, have proposed a strategy that can be applied in the organizations with various production profiles. According to them, EMAS implementation enables the gain of both environmental and financial advantages [21]. They have proposed, among others, the actions related to following environmental aspects: replacing the conventional energy with renewable energy, the reduction of raw materials consumption, and the reduction of emissions both greenhouse gas and volatile organic compounds [21]. González González et al., in the research published in 2018 [22], have analyzed the energy consumption in EMS certified German Hospitals. They have proposed the strategy and indicators which enable the comparison of energy efficiency between different hospitals. Although caring about the environment is widely recognized and understood, the EMS implementation can be still a problem, as evidenced by records of the number of organizations implementing these systems. Unfortunately, despite positive aspects of implementing EMS, relatively few organizations are interested in EMAS registration due to the reasonably high costs and 
the lack of encouragement from the public institutions [23]. An additional problem can be the scarce financial support available to the companies and the relatively complex administrative and bureaucratic procedure of registration [23]. Hajduk-Stelmachowicz has stressed, in the work published in 2018 [18], that EMAS specifies the indicators of environmental performance which should be included in declarations, but, unfortunately, it does not specify the way of presenting this information. For this reason, the comparative analysis of these indicators values is hampered, even in the case of companies having the same business profiles. As a result, institutions, e.g., public offices, rarely evaluate the environmental indicators in the field of energy efficiency due to the inability to monitor them, because the administration of these elements (e.g., energy use) is conducted by other entities [24]. Szyszka and Matuszak-Flejszman, in their article [25], have proposed the system recommendations which should be considered, among others, by the local authorities, national competent bodies, as well as organization representatives. It is important to analyze and evaluate the benefits of environmental management systems for companies and other institutions on an ongoing basis, as well as to identify barriers that still discourage organizations from implementing these tools [26]. Heras-Saizarbitoria et al., in a paper published in 2015 [27], have confirmed that the adoption intensity of EMAS in European Union countries is greater in economic sectors with higher environmental impact. However, on the other hand, the implementation intensity of EMAS in more polluting industries differs widely among EU member states, which may be related to the differences in incentives as well as regulatory reliefs for EMAS registered companies and other institutions [27].

It should be noted that Polish organizations which have already introduced ISO 14001 standard can implement EMAS with relatively little effort [28]. The basic reasons why the organizations should register for EMAS are, among others, corporate social responsibility (CSR), climate protection, increases in energy efficiency, use of renewable energy sources, legal compliance, supply chain management, and green public procurement (GPP) [24]. Although the international standard, ISO 14001, was published three years later than the first EMAS regulation, the interest of Polish organizations in implementing ISO 14001 is much greater. In January 2019, the total number of economic entities in Poland was equal to over 4 million, but only 68 organizations (356 locations) were registered in EMAS. At the same time, 3599 organizations (12,803 locations) were registered in EMAS in Europe [29]. It should be emphasized that most of them came from Germany (1193 organizations, 2130 locations), Italy (923 organizations, 5799 locations), Spain (803 organizations, 1000 locations), and Austria (252 organizations, 1172 locations) [26]. The research results given by EUROSTAT show that, in 2015, the highest number of implemented EMAS systems per million inhabitants was recorded in: Cyprus (62.5 organizations), Austria (29.9 organizations), Spain (23.5 organizations), Italy (17.3 organizations), Germany (15.2 organizations), and Denmark (10 organizations) [29]. In Poland this number was only 1.72 organizations per million inhabitants [26].

Additionally, it is disturbing that the number of Polish organizations which are cancelled, suspended, or resigned from EMAS has been growing since 2016 [30]. A similar phenomenon is observed in other European countries, where in recent years a growing number of organizations did not renew their certifications. For example, in Germany, 1402 organizations were registered in 2011, and 1193 in 2018, which means a decrease of 15\%. Similarly, in Italy, 1035 organizations were registered in EMAS in 2011, but in 2018 this number was equal to 923 organizations [31]. Merli and Preziosi, in an article published in 2018 [31], have ascertained that mostly small-sized organizations have the predisposition to renew their EMAS registrations in Italy. Additionally, they have found the negative link between the possession of standard ISO 14001 and the EMAS renewal intentions. Merli et al., in a paper published in 2018 [32], have pointed out that the implementation costs may be basic reasons for not renewing EMAS, both in the case of administrations and private-owned organizations in Italy. Preziosi et al. have reported, in the article published in 2016, that reasons for organizations' decisions to withdraw from EMAS are, 
inter alia, difficulties regarding system implementation and the lack of both human and financial resources [33].

The above situation prompts us to conduct further research on the factors influencing this state, starting from the motives and difficulties of EMAS implementations and ending with their benefits. The expanding and updating research in a changing situation is justified as it can be used to establish effective support tools for the organizations to encourage EMAS registration and thus maximize the assumptions of sustainability. The article deals with the issue of the implementation and functioning of EMSs in organizations based on survey research. The survey questions were directed to the organizations that have implemented EMAS (and previously had implemented ISO 14001) and to the organizations that have only implemented ISO 14001.

The main purpose of this article is to analyze and compare benefits and barriers to the implementation of ISO 14001 and EMAS by organizations. The paper attempts to answer the research questions: 1. Does the implementation of either ISO 14001 or EMAS bring the same benefits and barriers to organizations, even if ISO 14001 was previously implemented? 2. Does the system functioning duration in the company influence internal and external benefits resulting from EMS implementation? 3. Are economic aspects of EMS adoption as important for entrepreneurs as the ecological aspects? As mentioned above, this issue is important due to large and still deepening disproportions between the quantities of organizations registered in ISO 14001 and EMAS in Poland in recent years. The additional problem is an increasing number of companies which decide to withdraw from EMAS registration. The most important novelty in the research described in the current paper consists of checking whether organizations that previously implemented ISO 14001 still have difficulties and problems with implementing EMAS, or whether the organization's experience in implementing ISO can be a significant facilitation in further EMAS registration. Another novelty was the investigation if system functioning duration in the company influences internal and external benefits from EMS implementation. There is an important and still valid research question to assess whether the benefits of implementing EMAS are commensurate with difficulties related to this system introduction.

The article also contains the analysis of internal and external benefits resulting from EMAS and ISO 14001 implementation, taking into account the duration of the system functioning in the company. The answers to these questions and their analysis may be crucial for wider dissemination and further facilitating the EMS implementation. The analysis of difficulties allowed us to suggest ways of reducing them and propose future directions of research on this subject.

We hope that this article and similar investigations may contribute to better understanding of the above-mentioned problems, and thereby this knowledge will be helpful for government units, politicians, decision makers, and entrepreneurs to take specific actions, as soon as possible, to counteract this unfavorable trend. It should be emphasized that the opinion of entrepreneurs (in this case expressed in the form of answers to survey questions) may be a valuable and reliable source of information for decision makers.

The conclusions formulated on the basis of the research results may supplement the knowledge on this subject, which may contribute to such a change in regulations so that the implementation of EMS (especially EMAS) will be more simplified and, above all, more profitable for entrepreneurs. This issue is very important, because the measurable effect of implementing EMS is taking actions to protect the environment (air, water, and soil) and, above all, to counteract the unfavorable and disturbing climate changes. The more companies that adopt EMS, the more environmental benefits can be obtained. Additionally, people employed and cooperating with companies (employees, their families, external stakeholders, students of certified schools, etc.) may have high ecological awareness and can support pro-ecological activities also in everyday life. 


\section{Similarities and Differences between ISO 14001:2015 and EMAS Regulation}

The standard ISO 14001:2015 is developed by the International Organization for Standardization, which is non-governmental organization, whereas EMAS is issued by the European Union (Regulation (EC) No 1221/2009 of the European Parliament and of the Council of 25 November 2009) [18]. Definitions according to ISO 14001:2015 and EMAS Regulation describe environmental management system are as follows:

- ISO 14001:2015: "Part of the management system used to manage environmental aspects, fulfil compliance obligations, and address risks and opportunities" [17];

- EMAS: "Part of the overall management system, that includes organizational structure, planning activities, responsibilities, practices, procedures, processes, and resources for developing, implementing, achieving, and maintaining the environmental policy and managing the environmental aspects" [18].

Both systems are being improved and modified [34]. The official new version of ISO 14001 (ISO 14001:2015) was published in September 2015. This third edition [17] cancels and replaces the second edition ISO 14001:2004. Some of the changes introduced in standard ISO 14001:2015 bring it closer to EMAS. These changes take into account the lifecycle perspective when assessing the environmental aspects. No detailed lifecycle analysis is required, but the analysis of environmental aspects should cover the purchase of materials, design, production, transport and delivery, use, end-of-life treatment, and subsequent disposal (ISO 14001:2015, item A.6.1.2) [17]. In turn, the EMAS requirements take into account both direct and indirect environmental aspects more broadly than ISO 14001:2015 [35]. Selected differences between EMAS and ISO 14001:2015 are given in Table 1.

Table 1. Selected differences between EMAS and ISO 14001:2015. Source: Own elaboration based on [36-40].

\begin{tabular}{|c|c|c|}
\hline Elements & EMAS & ISO 14001:2015 \\
\hline Type of issued organization: & Governmental & Non-governmental \\
\hline Name of issued organization: & European Parliament and Council & $\begin{array}{l}\text { International Organization } \\
\text { for Standardization }\end{array}$ \\
\hline Objective: & $\begin{array}{l}\text { Environmental performance } \\
\text { improvement }\end{array}$ & $\begin{array}{l}\text { Environmental performance enhancement } \\
\text { through EMS improvement }\end{array}$ \\
\hline Range: & European & International \\
\hline Nature: & Public regulation & Private standard \\
\hline Main drivers to adopt EMS: & Internal motivation & Pressure of external stakeholders \\
\hline $\begin{array}{l}\text { Dialogue with external parties } \\
\text { (and external reporting): }\end{array}$ & Mandatory & Voluntary \\
\hline $\begin{array}{l}\text { Official registration by } \\
\text { authorities: }\end{array}$ & $\begin{array}{l}\text { Publicly accessible register record } \\
\text { (organization receives } \\
\text { the registration number) }\end{array}$ & No official register \\
\hline Audits: & $\begin{array}{l}\text { Inspection of documents and visits in } \\
\text { institutions carried out according to } \\
\text { regulation. Evaluation of environmental } \\
\text { performance improvement. Data from } \\
\text { environmental statement needs validation. }\end{array}$ & $\begin{array}{l}\text { No certification rules in standard (different } \\
\text { standards for auditing and certification). } \\
\text { Evaluation of EMS performance without } \\
\text { specified frequency. }\end{array}$ \\
\hline Environmental aspects: & $\begin{array}{l}\text { Comprehensive initial environmental review } \\
\text { of the current status of activities, products } \\
\text { and services. }\end{array}$ & $\begin{array}{l}\text { Requires only a procedure to identify } \\
\text { environmental aspects. Initial review is } \\
\text { recommended, but not required. }\end{array}$ \\
\hline
\end{tabular}

In 2017, amendments were introduced to the annexes of EMAS (Commission Regulation (EU) 2017/1505 of 28 August 2017) [19] in order to adapt them to the new requirements of ISO 14001:2015. This means that for companies that already have an environmental management system compliant with ISO 14001:2015, it will also be easier to comply with EMAS [31]. It should be emphasized that both schemes are voluntary for organizations 
and have global geographical applicability [36]. They can be implemented by large and small companies, public and private organizations alike. The new EMAS version includes all the requirements of ISO 14001:2015, with additional elements, such as an environmental declaration and the commitment of all employees. Both standards also cover new areas: life cycle perspective, organizational context, needs and expectations of the stakeholders. Similarities between the systems include the monitoring of environmental performance indicators (e.g., ISO 14001:2015, items 6.2.2 and 9.1.1), and the use of audits to monitor environmental processes in terms of compliance and improvement. ISO 14001:2015 requires the identification of environmental aspects and impacts, while EMAS requires an initial comprehensive environmental review of processes [37]. EMAS provides a record of all registered organizations, which is not available for ISO 14001:2015. Additionally, EMAS has a stricter interpretation of environmental processes planning and management [36]. Benefits of EMS implementation are to some extent common to both systems; however, the EMAS implementation may generate additional benefits, as shown in Table 2.

Table 2. The selected benefits of ISO 14001 certification and EMAS registration. Source: Own elaboration based on [36,37,41,42].

\section{The Benefits of ISO 14001 Certification and EMAS Registration}

- the reduction of energy consumption and resultant energy savings;

- climate protection due to the energy management and reduction of greenhouse gases emissions;

- the reduction of raw material consumption;

- lower insurance rates due to reduction of the environmental failure risk;

- the reduction of waste disposal costs;

- the lower fees related to the use of environmental resources;

- the reduction of the risk of lawsuits related to environmental damage;

- the improvement of image by reducing the negative impact on the environment;

- the improvement of organization management;

- the quick detection of places and processes threatening the environment thanks to regular internal and external audits;

- for energy-intensive enterprises: the possibility of obtaining an exemption from excise duty for activities subject to taxation, the subject of which are coal or gas products intended for heating purposes;

- ISO 14001 certification and entry in the EMAS register are an important marketing asset.

$$
\text { The additional benefits of EMAS registration }
$$

- the entry in a publicly available register;

- for large companies: the exemption from the obligation to conduct an energy audit of the enterprise (subject to additional conditions);

- for public sector entities: the confirmation of the implementation of energy efficiency tasks;

- the transparent data provided by the mandatory and verified statement of registered organization;

- the increase in the organization's credibility thanks to the environmental declaration;

- the improved stakeholder relationships;

- the possibility of benchmarking in the field of environmental protection;

- the exemption from the registration fee for entry in the database on products and packaging and on waste management.

\section{Materials and Methods}

The aim of the research was to compare the benefits and barriers to the implementation and operation of ISO14001:2015 and EMAS in the selected Polish companies. The study was conducted in 2019/2020 in the form of a written anonymous survey sent to various organizations. The questionnaire was prepared and developed by authors of the publication. The questions included in the questionnaire and the answers to be chosen were specified based on the literature review and the previous research of the first author [22]. The survey was structured in a way so that readers could compare the answers of companies that have implemented the ISO 14001 standard and those that have implemented the EMAS system (these organizations had previously implemented ISO 14001). It should be emphasized that all organizations with implemented EMAS, although they had previously implemented ISO 14001, answered the questions only in terms of implementing EMAS. The questionnaire was sent to 40 organizations that had implemented the EMAS system and 45 that had implemented ISO 14001. The completed questionnaires were received from 25 EMAS certified companies and 25 that had introduced ISO 14001. These organizations differed 
in terms of both the industry and the location. Due to the number of people employed, they were small enterprises (less than 50 employees) and medium-sized enterprises (less than 250 employees). The activities of the surveyed organizations were related to the water and sewage management, waste management, energy production, energy supply, and public administration. The questionnaire consisted of 5 closed questions, in which the respondents were to indicate the most important factors from among the provided answers; it was also possible to indicate their own additional answer. For each of the questions, there were several formulated answers (5-8 depending on the question), with a request to indicate the most important, from the point of view of a given organization, and if necessary to indicate other than those given in the question. Each answer had the same weight and the organizations chose $2-4$ answers from among the few given (only those that were the most important to them). The questions were aimed at determining the reasons why the organization decided to implement EMS, as well as indicating the difficulties and positive aspects of implementing the systems. Then collected data were analyzed and results were discussed. Questions related to issues such as:

- Reasons for implementing the EMAS/ISO 14001 system in enterprises;

- Difficulties in implementing EMAS/ISO 14001;

- Internal benefits resulting from the implementation of EMAS/ISO 14001;

- External benefits resulting from the implementation of EMAS/ISO 14001;

- Costs related to the implementation of EMAS/ISO 14001 in the enterprise.

Two questions related to benefits of implementing both systems. According to authors of the article, the knowledge of benefits of EMS implementation is important due to the large disproportions between the number of organizations registered in ISO 14001 and in EMAS. It is important to know the benefits of introducing EMAS in order to assess whether they are commensurate with difficulties of the system implementation.

The survey also asked about:

- the year of registration of the system in the organization;

- the number of employees.

The organizations surveyed on EMAS implementation were asked about prior ISO 14001 certification. In approximately $50 \%$ of the surveyed organizations, both ISO and EMAS systems had been in operation for over 5 years; therefore, there was an attempt to assess the impact of the EMS operating duration (for less than 5 years or for over 5 years) on the benefits perceived by the organization.

\section{Research Results and Discussion}

The current chapter presents the results of the conducted survey. The questions and answer choices, as well as survey results, are presented graphically in the Figures 1-9.

The first question of the survey concerned the reasons for implementing EMAS/ISO 14001 in companies. An analysis of the answers to this question indicates that these two EMS are often adopted by organizations for different reasons (Figure 1). The majority of the surveyed organizations $(60 \%)$ indicated the pursuit of environmental improvement as the main reason for implementing ISO 14001. The second important reason for the implementation of this standard was the plan to increase the knowledge and environmental awareness of organizations' employees. These answers were also selected by organizations that had implemented EMAS. In the case of both EMAS and ISO 14001, the willingness to strive for environmental improvement (reduction of energy and raw material consumption, reduction of emissions, etc.) was indicated as an important reason for implementing the systems. This result shows the growing environmental awareness of entrepreneurs. This is also confirmed by the research conducted by other authors. Biondi et al., in the paper published in 2000 [43], found that one of the most relevant advantages of EMAS implementation was better legal compliance. The authors emphasized that in many cases, the technicians working in the small and medium sized enterprises possessed a good knowledge of the production and were aware of basic environmental problems, as well as 
being capable of managing them [43]. Ferrón-Vílchez, in her article published in 2016 [44], emphasized that the foundations of ISO 14001 are the compliance with environmental regulations, pollution prevention, as well as continual improvement of the environmental performance of the company. Iatridis and Kesidou have concluded in their article published in 2018 [45] that the organizations can use implemented ISO 14001 in order to improve their reputation, e.g., showing their environmental commitment. The results of other authors' studies confirm that the ISO 14001 standard is often put in place as a response to external pressure related to the deteriorating state of the environment (striving to reduce the consumption of energy and raw materials, to reduce the emissions, to increase the ecological knowledge and awareness of employees, the desire to adapt to the expectations or requirements of customers and the market, etc.) [46]. The study of Waxin et al., published in 2019 [47], indicates that factors such as compliance with regulations and standards, as well as improvement of environmental performance, are very important drivers for ISO 14001 certifications. However, the most important premise for the implementation of EMAS (indicated by $60 \%$ of the surveyed organizations) was to improve the innovativeness, as well as the company's image and competition on the market [47]. By contrast, this reason for implementing ISO 14001 was indicated in the current survey by only $8 \%$ of the organizations. This demonstrates high internal motivation of organizations which have implemented EMAS. This trend is also indicated by Neugebauer in the study conducted in 2012 [48]. The study carried out by Morrow and Rondinelli in 2002 also shows that the implementation of EMAS by organizations is affected by factors such as improving their image or gaining a competitive advantage on the market [49]. As a less important reason for the implementation of both systems, the organizations indicated the possibility of easier access to financial resources, e.g., from various funds allocated for environmental protection or more favorable loans. In total, such answer was provided by eight organizations.

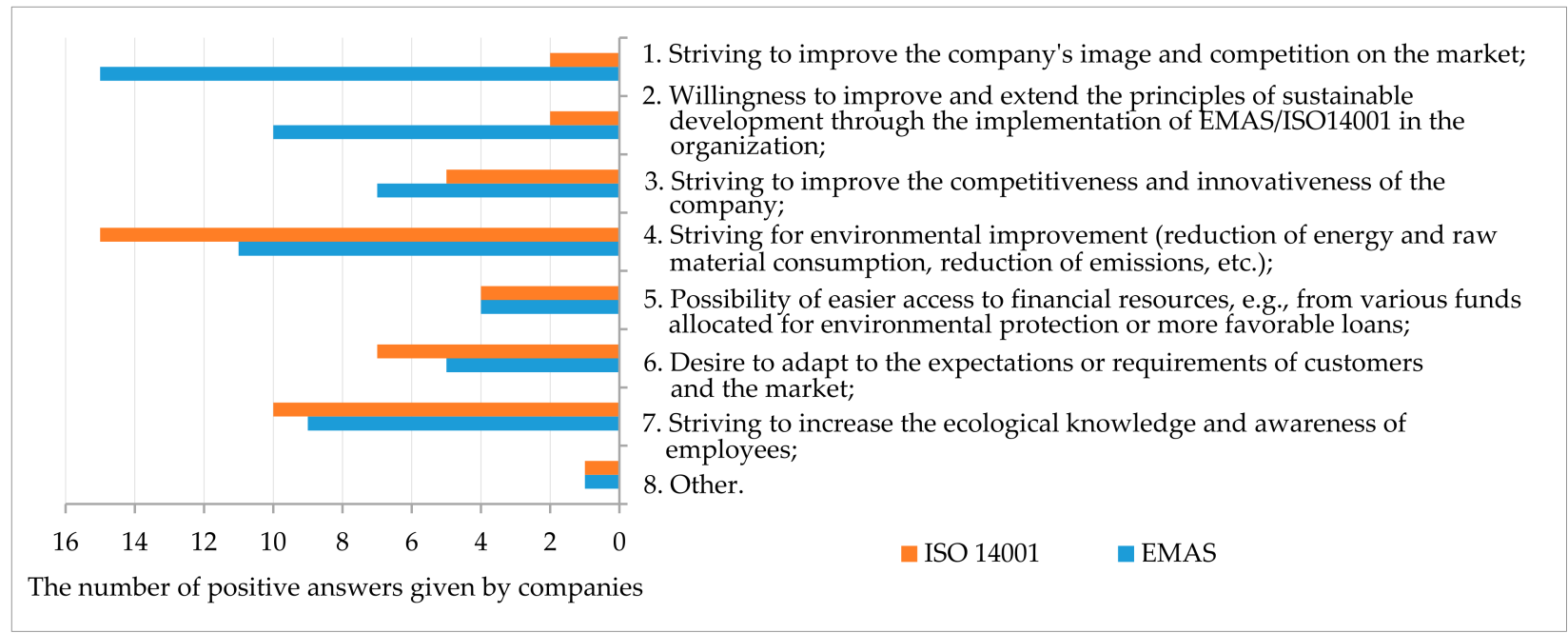

Figure 1. Answers to the first question of the survey: Reasons for EMAS/ISO14001 implementation in companies.

The second question of the survey concerned the identification of the most important difficulties in the implementation of EMAS/ISO14001 (Figure 2). In the implementation of both EMAS (52\% of organizations) and ISO 14001 (48\% of organizations), knowledgerelated difficulties and organizational problems with the preparation of documentation were indicated as the most important difficulty. Although the new standard ISO 14001:2015 has reduced the amount of documentation, the preparation of documentation is still a significant barrier for companies. This has been confirmed by other studies [50-52]. Seifert, in an article published in 2018 [50], described the results of a survey conducted in German hospitals. She ascertained that an inexperience with the EMAS system and environmental issues may increase the costs for hospitals, e.g., due to the engagement of a professional consultant. The author proposed some recommendations to promote EMAS implementa- 
tions, e.g., specific information on EMAS and best practices, support from associations, the initial experience with other certifications. It can be very helpful to have an exchange of experience before EMAS implementation [50]. Heras-Saizarbitoria et al., in an article devoted to ISO 14001 audits [52], concluded that the International Organization for Standardization, as well as certification bodies, ought to adopt a more substantive approach to the standard implementation and verification (for example, the stakeholder inclusiveness promotion). The authors underlined that the clear and thorough environmental performance analysis conducted during certification audits influence the implementation of substantial changes to reduce the environmental impact of organization [52]. Carrillo-Labella et al., in the research published in 2020, revealed that the surveyed employees declared that bureaucratic procedures are a problem (e.g., the excessive paperwork and the long time needed for it to be accepted, as well as the periodic audits to which they are subjected) [53]. This creates resistance among the employees, which is also confirmed by the first author's own research (limited knowledge among the staff regarding the benefits of implementation or resistance to implementation of changes-nine indications in the implementation of ISO 14001 standard).

The time invested in EMS preparation and implementation was also indicated as another significant difficulty during EMAS introduction (11 answers). It turns out that organizations that previously implemented ISO 14001 still have substantive organizational problems with the implementation of EMAS. It is noteworthy that few organizations indicated financial problems as a serious obstacle to the implementation of EMS. In the case of ISO 14001, the financial problems were indicated by two organizations, and three in the case of EMAS, which represent $8 \%$ and $12 \%$ of companies which took the survey, respectively.

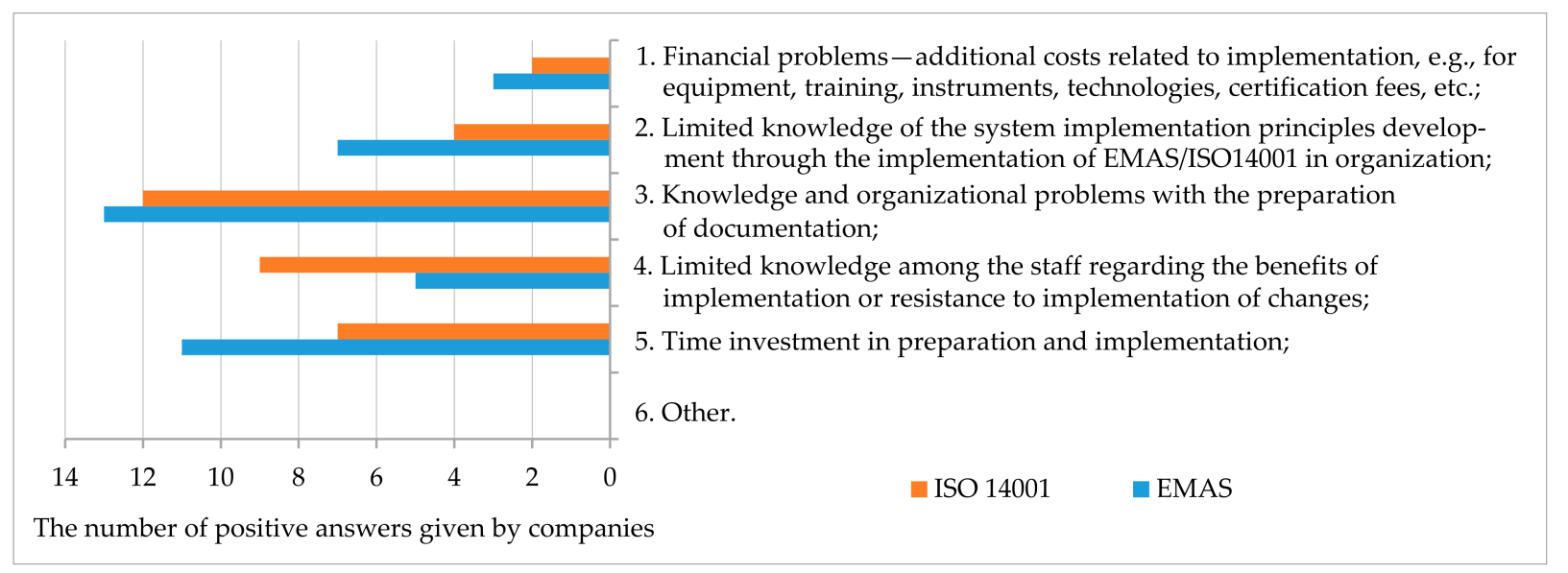

Figure 2. Answers to the second question of the survey: Difficulties encountered during EMAS/ISO14001 implementation.

The third question of the survey was to identify the internal benefits of EMAS/ISO14001 implementation. The most important benefits indicated included the compliance of the organization with regulations, improvement of environmental protection standards in the implementation of either ISO 14001 or EMAS, and improvement of the company's functioning. In the case of ISO 14001, this response was indicated by $48 \%$ of the organizations which took the survey; however, in the case of EMAS, this percentage was equal to $80 \%$ (Figure 3). This means that organizations that have implemented both systems, first ISO 14001 and then EMAS, very clearly appreciate the compliance with the regulations and perceive the benefits of increasing environmental protection standards after their introduction. 


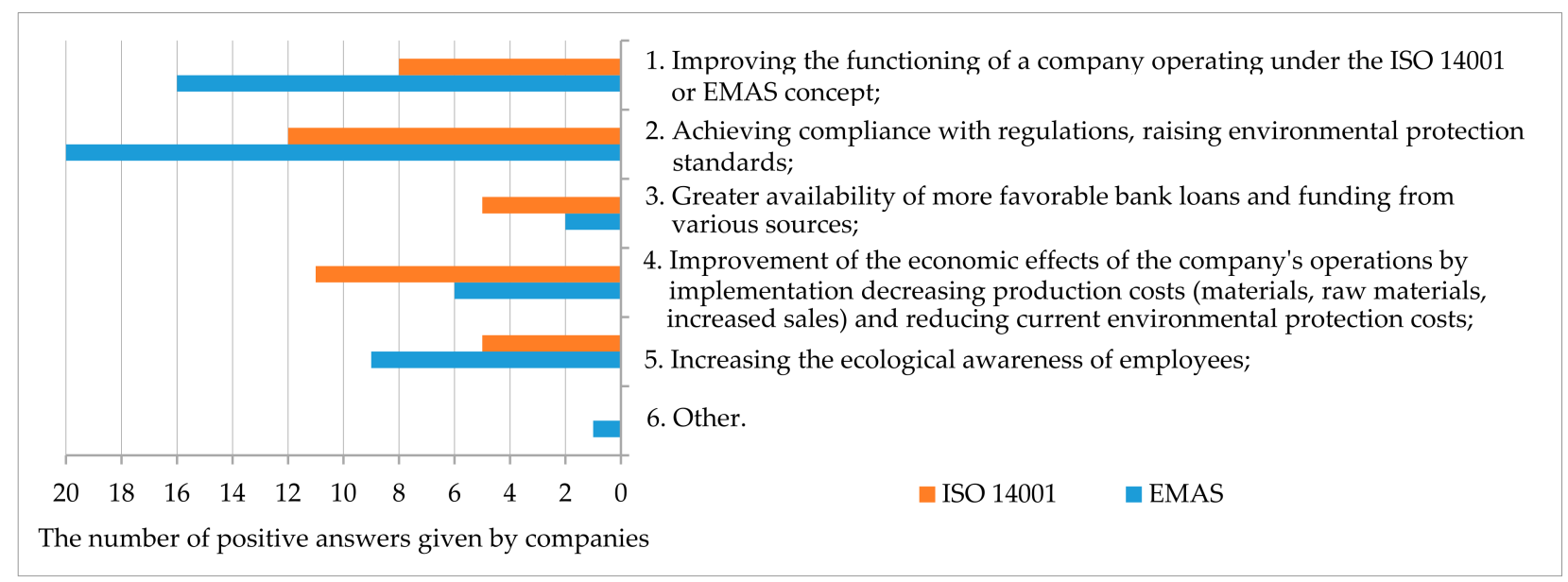

Figure 3. Answers to the third question of the survey: Internal benefits stemming from EMAS/ISO14001 implementation.

The improved compliance with regulations also contributes to easier day-to-day business management [54]. Other authors' studies confirm that achieving compliance, as well as raising environmental standards, are crucial for an organization and appear as one of the most important benefits [55-57]. Ikram et al., in an article published in 2019 [55], have confirmed that EMS certified organizations have better performance than companies which have not implemented EMS. According to them, EMS may improve both the corporate sustainability and corporate business. They have underlined that sustainable development is crucial for contemporary organizations, taking into account social, economic, and environmental aspects [55]. Testa et al., in an article published in 2018 [56], found that the internalization of standard requirements in terms of both strategies and the operational procedures may be helpful to achieve the environmental performance improvement. On the other hand, Díaz de Junguitu and Allur, in an article published in 2019 [57], ascertained that EMS adoption helped compliance with applicable regulations, but this incentive seemed to be unimportant. They concluded that in many cases, organizations and institutions comply with environmental regulations even prior to the EMS implementation [57].

Companies that have implemented ISO 14001 also indicated that after the implementation there was a noticeable improvement in the economic effects of the company's activity through the reduction of production costs (materials, raw materials, increased sales), and a reduction of current costs of environmental protection among the benefits. The lowest number of responses included the answer "greater availability of more favorable bank loans and funding from various sources". In the case of EMAS, this answer was indicated only by two organizations, and only by five for ISO 14001. This suggests that financial benefits are not an incentive for the companies to implement these schemes and are not perceived as a significant benefit. Similar conclusions are formulated by Riaz and Saeed in an article published in 2020. They ascertained that, taking into account the financial aspects, ISO 14001 can be negatively evaluated by investors [58]. However, it should be emphasized that results presented in our paper suggest that, in Poland, the financial aspects of EMAS may be evaluated worse than those of ISO 14001.

The fourth question of the survey was to identify the external benefits stemming from EMAS/ISO14001 implementation (Figure 4). The results show that the most important premise for the implementation of EMAS system was that the "green image" is beneficial for companies. This answer was indicated by 22 companies, which represents $88 \%$ of surveyed organizations that implemented EMAS. This enables us to conclude that the implementation of EMAS, which is a more challenging system, may considerably improve the ecological image of company and increase its competitiveness on the market to a greater extent than ISO 14001 certification. In the case of ISO 14001, the most frequently answer was "Improvement of the state of the environment and environmental safety of the business". 
This answer was indicated by 12 companies, which represents $48 \%$ of surveyed ISO 14001 certified organizations. Other authors point out similar benefits indicated by entrepreneurs implementing EMS [55,59]. Ikram et al., in an article published in 2019 [55], concluded that EMS certified companies have positive effect on both environmental protection and society. Martín-Peña et al., in an article published in 2014 [59], ascertained that the most important benefits related to EMS implementation were the reduction of the use of energy, raw materials and water. Additionally, they have concluded that EMS implementation positively influences the company image and the cost reductions. Furthermore, companies which implemented ISO 14001 and EMAS similarly often indicated the answer that the organization is more attractive to potential customers. What is more, entrepreneurs are aware of benefits connected with increasing the competitiveness of the organization on the market.

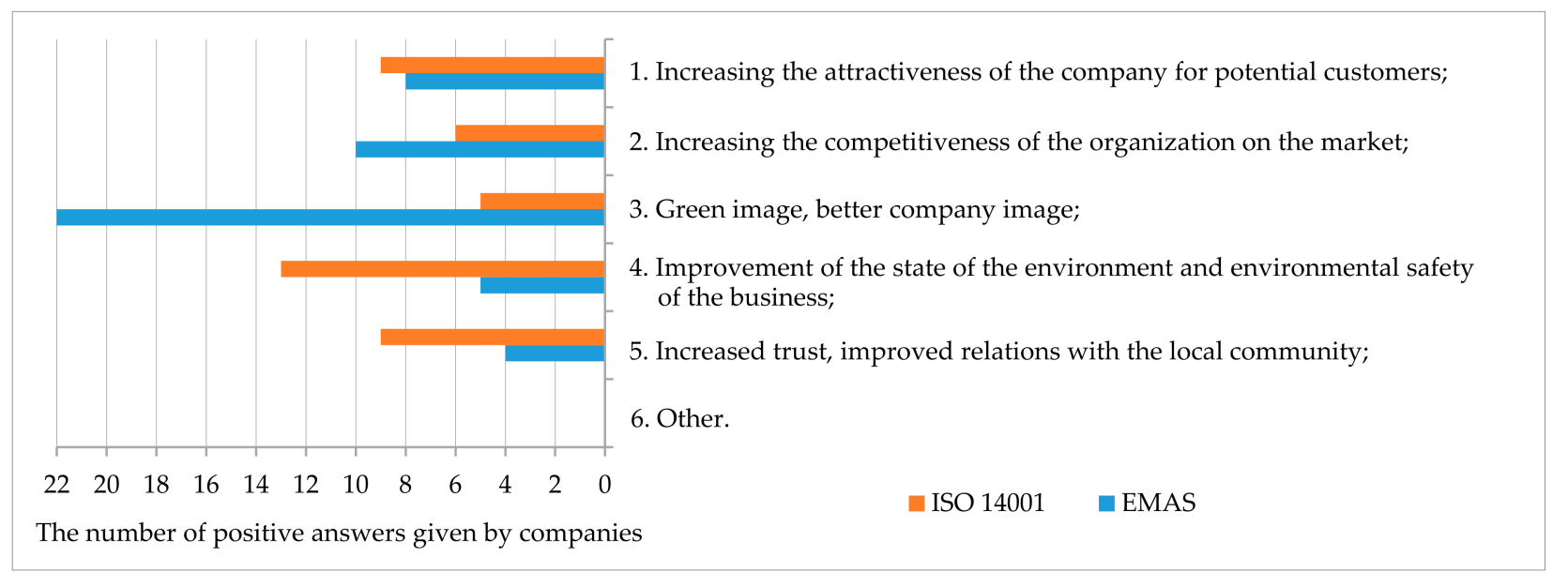

Figure 4. Answers to the fourth question of the survey: External benefits stemming from EMAS/ISO14001 implementation.

The fifth question of the survey was to identify the most burdensome costs associated with the implementation of EMAS/ISO14001 in the company (Figure 5). Although in the answers to the second question (see Figure 2), few organizations indicated financial problems as a serious obstacle to the EMS implementation, the fifth question is specific and indicates areas where financial outlays are important. Results of the survey confirm that in the case of ISO 14001 implementation, companies mainly indicate costs of staff training and an increase in environmental investments, while in the case of EMAS, the highest costs incurred by enterprises are related to certification and audits. The percentage of organizations with implemented EMAS which have indicated this answer is equal to $60 \%$. These trends are confirmed in the study conducted by Jaźwińska (2013) [60], where the largest amounts of implementation costs were system certification ( $100 \%$ of responses) and training. Costs of the crew training during the EMAS implementation in the analyzed study were not of key importance, but were visible in the implementation of ISO 14001. The reason of this may be that crews, while implementing EMAS, had previously received ISO 14001 training and training was partially based on the acquired knowledge. 


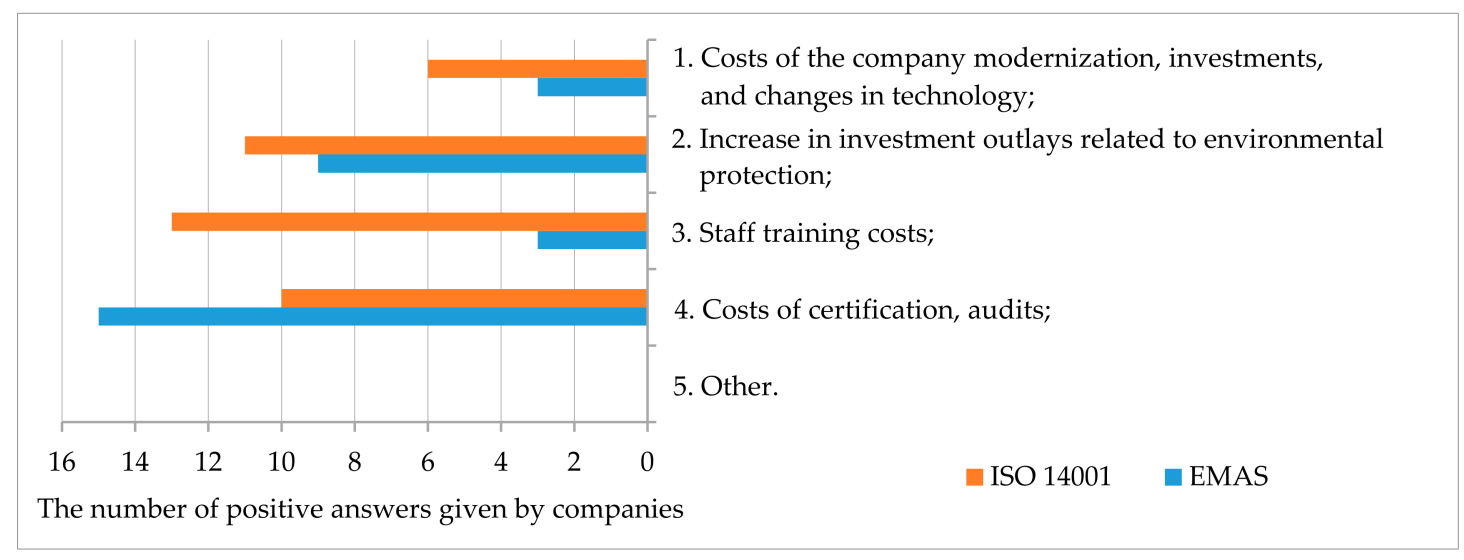

Figure 5. Answers to the fifth question of the survey: Costs of EMAS/ISO14001 implementation in a company.

The high costs incurred for the implementation of EMS are described in numerous publications [61-65]. The research carried out by other authors also shows that entrepreneurs, while implementing ISO 14001, complain about high costs of additional outlays on necessary investments, e.g., related to environmental protection [66-68]. Heras-Saizarbitoria et al., in an article published in 2016 [66], underlined that during a period of economic crisis the motivations behind the certificate implementation may have an impact on the renewal of EMAS certificates. They concluded that the higher the internal reasons to adopt EMS, the lower the possibility of not renewing the certificate. According to their conclusions, both the initial investment made by the organization in order to adopt EMAS and maintenance costs do not influence the likelihood of not renewing the certification [60]. In turn, Boiral at al., in the research published in 2018 [67], concluded that adoption of ISO 14001 positively influences the image, internal practices, and environmental awareness of institutions, but, on the other hand, may generate implementation costs, paperwork or bureaucracy. According to Boiral et al., this may result in a situation where some companies and institutions may adopt ISO 14001 only symbolically, without substantial changes or care for the environment [67]. It can be noted that in Poland, entrepreneurs often choose ISO 14001 over EMAS because they find EMAS more difficult and more expensive [28], which has been confirmed in the current research. However, there are Polish organizations which have successfully implemented EMAS and achieve many benefits related to water and energy savings, proper waste management, customer trust, and the economic benefits [68]. The costs of company modernization (especially in case of EMAS) were reported by relatively small number of organizations. These companies probably have borne the majority of these costs and investments during previous ISO 14001 implementation.

The analysis of research results prompted authors to assess the impact of the EMS operating duration on benefits perceived by the organizations. Analyzed organizations were divided into two groups: companies with EMS functioning time for less than five years and companies with EMS functioning time for over five years. In approximately $50 \%$ of surveyed organizations, ISO 14001 and EMAS systems had been in operation for over five years and benefits indicated by them were often different than in organizations in which EMS operated for shorter amounts of time. Figures 6 and 7 show the analysis of survey answers concerning internal benefits of EMS implementation depending on the system functioning duration.

The answer regarding the internal benefits of improving the functioning of a company operating under the EMAS concept was indicated by $90.9 \%$ of organizations in which the system had been operating for over five years (Figure 6). The same benefit was reported much less $(42.8 \%)$ by organizations in which EMAS operated for up to five years. Organizations that had implemented ISO 14001 also appreciated the impact of the system implementation on the improvement of the company's operation after a longer period of system functioning, but in this case their percentage was lower (36.4\%) than in the case of 
EMAS (see Figure 7). The positive impact of the longer period of EMS operation was also found for the answers 4 and 5, concerning the improvement of the economic effects of the company's functioning and the increase in the environmental awareness of employees. It should be emphasized that answer 2 , concerning the achieving compliance with regulations and raising environmental protection standards, was the internal benefit indicated by a relatively high number of companies, especially those which had implemented EMAS in the last five years $(85.7 \%)$. However, it should also be noted that few EMAS certified organizations indicated answer 3, concerning greater availability of more favorable bank loans and funding from various sources, regardless of the system functioning duration.

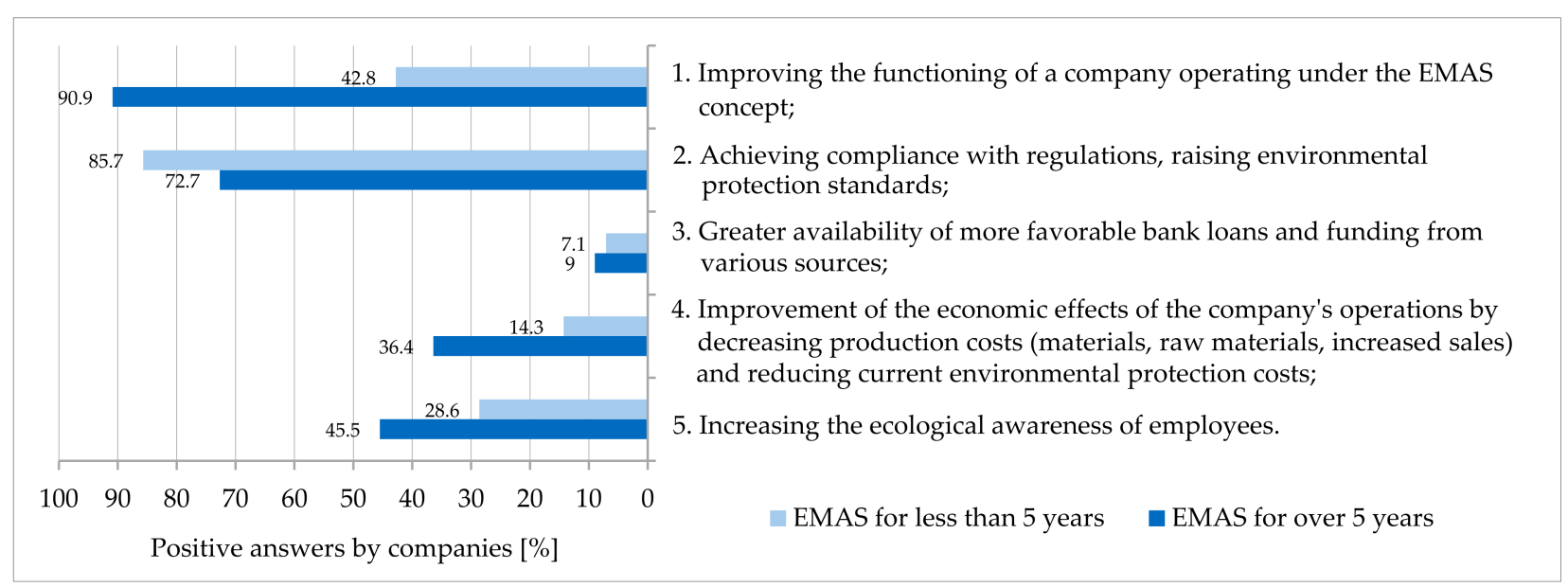

Figure 6. Analysis of internal benefits resulting from the implementation of EMAS depending on the duration of the system operation in organizations.

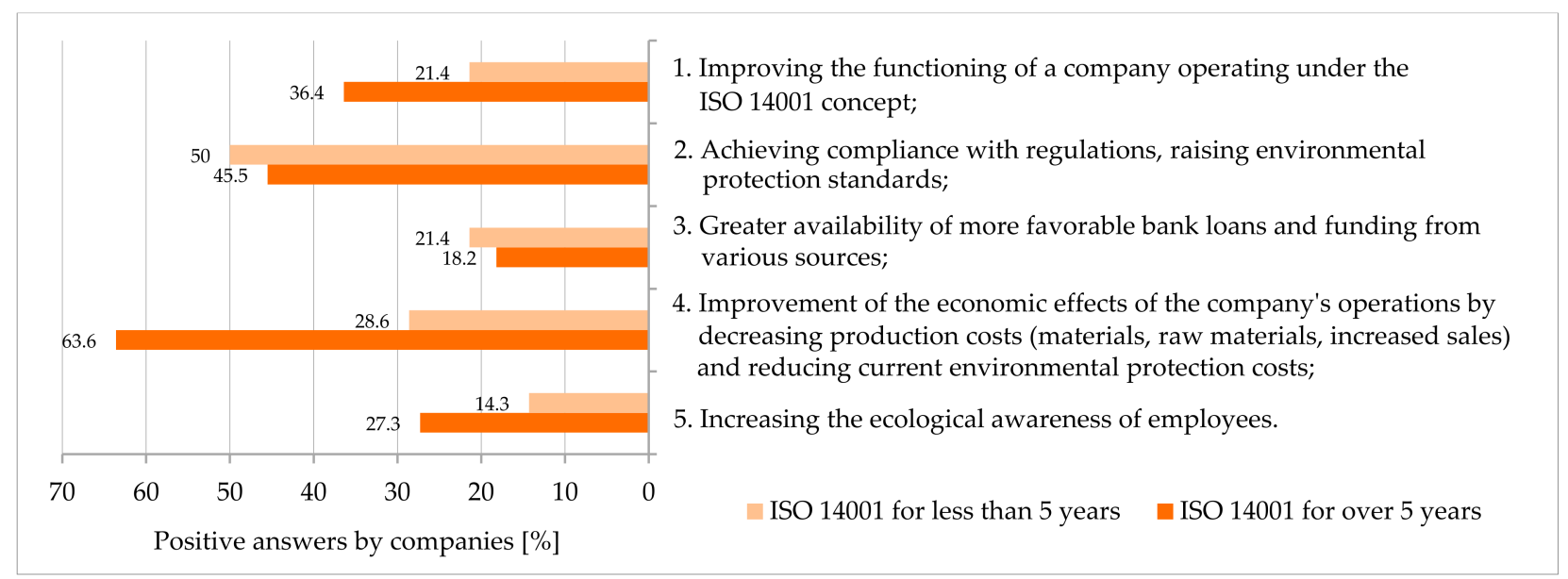

Figure 7. Analysis of internal benefits resulting from the implementation ISO 14001 depending on the duration of the system operation in organizations.

Figures 8 and 9 show the analysis of survey answers concerning the external benefits of EMS implementation depending on the system functioning duration. 


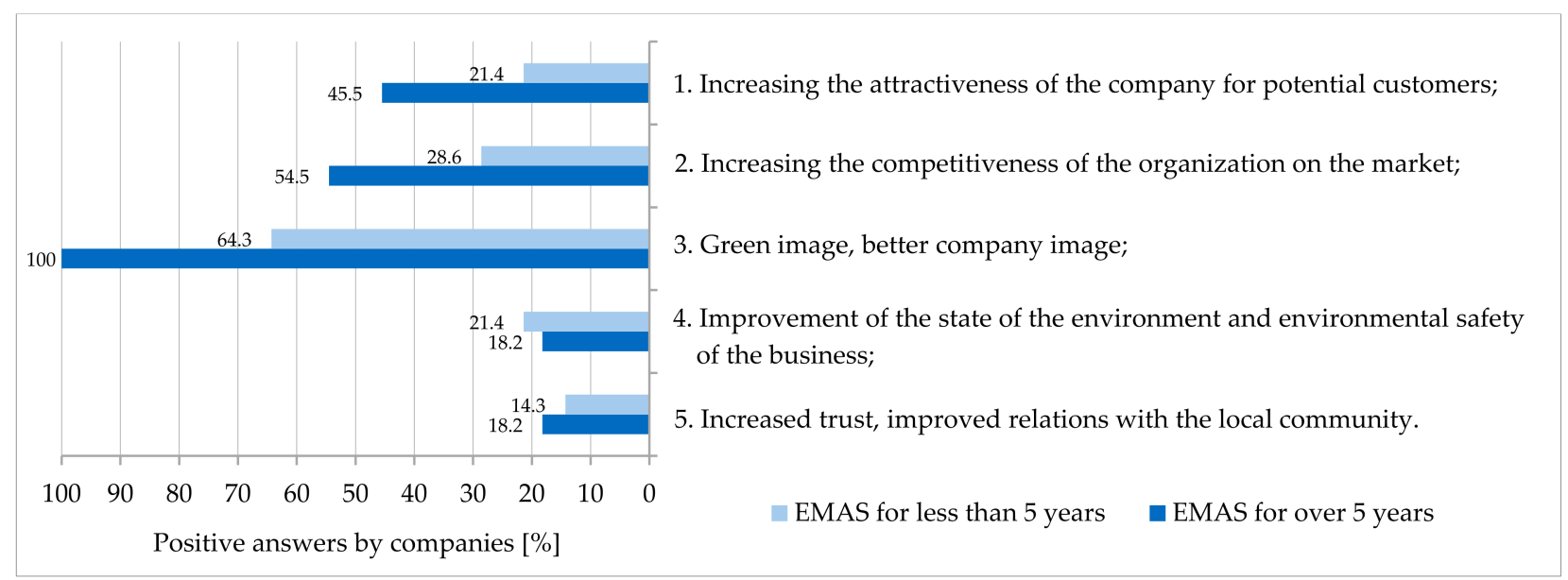

Figure 8. Analysis of the external benefits resulting from the implementation of EMAS depending on the duration of the system operation in organizations.

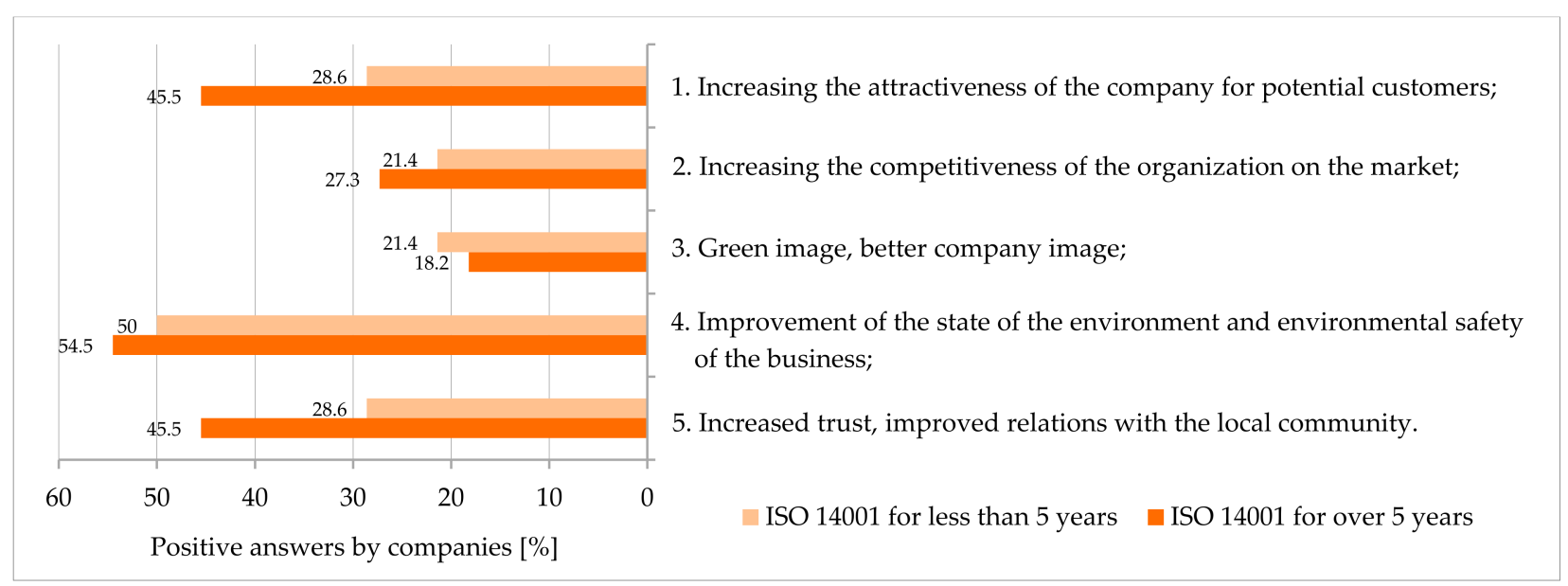

Figure 9. Analysis of the external benefits resulting from the implementation ISO 14001 depending on the duration of the system operation in organizations.

The results presented in Figure 8 show that the most important external benefit indicated by EMAS certified organizations was to build a better image of a "green" company. This answer was indicated by $100 \%$ of enterprises in which EMAS operated for over five years. However, on the other hand, the "green" image of organization was the least significant advantage for ISO 14001 certified companies (Figure 9). The most important external benefit for organizations that had implemented ISO 14001 was improvement of the state of the environment and environmental safety of the business. Such an answer was provided by more than half of the surveyed companies in which the system operated for over five years (54.5\%). The next important external benefit for ISO 14001 certified companies was the increased trust and improved relations with the local community ( $45.5 \%$ of companies in which the system was functioning for over five years). These external benefits (answers 4 and 5), in contrast, were less significant for EMAS certified companies.

\section{Summary and Conclusions}

Both analyzed systems are based on the Deming cycle, which functions according to the idea of continuous improvement of activities related to environmental aspects of the organization (in the case of the systems discussed above). Despite the many environmental actions which are taken, the pollution of air, water and soil is still a serious problem. EMSs are useful tools for organizations and other institutions to manage environmental aspects that are also relevant to sustainable development. 
The novelty and added value of this research, which supplements the research carried out by other authors, consisted of checking whether the organization's experience in implementing EMAS, after the earlier implementation of ISO 14001, is a significant facilitation, and whether the duration of the system operation in the organization affects the benefits perceived by the organization. The next important novelty was the investigation of whether system functioning duration in the company influences internal and external benefits from EMS implementation. These questions are important due to the decreasing number of implementations of EMAS in Poland in recent years, and the increasing number of withdrawals of organizations from EMAS. It is important to assess whether benefits of implementing EMAS are commensurate with the difficulties related to the implementation of the system. The results of the survey and their analysis indicate that these two standards are not always adopted for the same reasons. Although the results of the survey indicated that the most important objective for the implementation of ISO 14001 and EMAS by organizations was to reduce their negative environmental impact, the most important rationale for choosing EMAS was to improve the company's image and competition on the market and to make the company more innovative. This answer was indicated by only $8 \%$ of organizations as the most important reason for implementing the ISO 14001 standard. This indicates a high internal motivation of organizations implementing EMAS, while ISO 14001 is often created as a response to external pressure due to the deteriorating state of the environment.

The survey results indicate that the implementation of both EMAS and ISO 14001 is seriously hampered by difficulties in terms of knowledge-related and organizational problems with the preparation of documentation, as well as the time required for implementation. Despite some of the introduced simplifications, the preparation of documentation is still a major barrier. One in three organizations with ISO 14001 indicated difficulties in implementing the standard due to limited knowledge of the benefits of implementation among the employees and the resistance of staff to change. This state of affairs is probably a result of insufficient environmental knowledge and convictions amid a part of the society regarding the need to act for environmental protection and sustainable development.

Organizations that have implemented the systems indicated internal and external benefits resulting from their adoption. The most important internal benefits from the implementation of both ISO 14001 or EMAS were indicated to be compliance of the organization with the regulations, improvement of environmental protection standards, and improvement of the company's functioning. Organizations that have implemented EMAS have also indicated improvements in the functioning of the company as a result of the scheme. When analyzing the external benefits, it should be emphasized that in the case of EMAS, the most important benefit indicated by organizations was to build a better image of a "green" company. In the case of ISO 14001, there was no clearly dominant answer; all responses were in a similar area, i.e., benefits related to the improvement of the environment and ecological safety of the business. A detailed answer to the question regarding the costs incurred indicated that in the case of implementation of ISO 14001, companies mainly included costs of staff training and an increase in environmental investments, while in the case of EMAS, the highest costs incurred were related to certification and audits.

The research results are limited because they concern only Polish organizations. However, many results are in line with findings and conclusions formulated by authors from other countries. Further investigations should be conducted, e.g., in other industries (or schools, offices) and with use of other questions.

The following conclusions can be drawn from the survey:

1. Results of the research indicate that the knowledge-based and organizational problems with preparing the documentation, as well as the time required, are much more significant than the financial problems associated with implementing either of the systems. Even those organizations which previously implemented ISO 14001 still have substantive organizational problems with the implementation of EMAS. Further efforts to simplify the implementation of the systems are therefore desirable. It is nec- 
essary to raise the employees' awareness of environmental protection and sustainable development measures.

2. After the implementation of either EMAS or ISO 14001, companies recognize the benefits of implementing systems. These include: increasing the compliance of the organization with the regulations, increasing the attractiveness of the company for potential customers, and increasing the competitiveness of the organization on the market, as well as an improved "green" image of the company.

3. The research shows that Polish organizations, when deciding to implement the EMAS system, most often saw benefits related to the improvement of the image and "environmental" motives. Economic benefits were rarely considered.

4. It was found that the perception of internal and external benefits by organizations is related to the period of functioning of systems in the organization. In general, extending the time of either EMAS or ISO 14001 certification of organizations had a positive effect on the level of observed benefits.

5. Cost studies indicate that in the case of ISO 14001 implementation, these mainly included costs of staff training and an increase in environmental investments, while in the case of EMAS, the highest costs incurred were related to certification and audits. Studies on the possibility of reducing these costs and providing financial assistance to organizations implementing the schemes are indicated.

6. Benefit analysis shows that it is necessary to strengthen economic incentives in order to enable the widest possible dissemination of environmental management systems among companies. It may contribute to an increase in EMS implementations, which may lead to more sustainable development and climate change mitigation, inter alia, by the increase in energy management efficiency, reduction of energy and raw materials consumption, use of renewable energy sources, reduction of greenhouse gas emissions, as well as through the protection of water resources.

On the basis of the conducted research, we can formulate some recommendations which could be helpful for government units, politicians, decision makers, and entrepreneurs to take actions to support organizations and institutions in decisions about EMS implementation:

- Companies indicated answers concerning the financial incentives related to EMS implementation only to a small extent. Therefore, we postulate that the financial benefits and incentives for companies adopting EMS (including EMAS) should be better and more clearly defined;

- Relevant legislation should support initiatives related to EMS implementation. Properly prepared and simplified legal regulations should support these initiatives;

- The registration procedure should be simplified, and the bureaucracy and paperwork (especially in EMAS) should be reduced. The authors also call for greater openness and help from the administration to make registration more friendly;

- We recommend more activities which will promote EMS implementation in organizations, industrial plants, institutions, schools, offices, hospitals, etc. At the same time, the pro-ecological activities should be promoted in the society.

Author Contributions: Conceptualization, A.O.-K. and E.O.; methodology, A.O.-K. and E.O.; software, A.O.-K. and I.D.; formal analysis, A.O.-K.; investigation, A.O.-K. and E.O.; resources, A.O.-K.; data curation, A.O.-K., writing-original draft preparation, A.O.-K. and I.D.; writing-review and editing, A.O.-K., I.D. and E.O.; visualization, A.O.-K. and I.D.; supervision, A.O.-K. and E.O.; project administration, A.O.-K. All authors have read and agreed to the published version of the manuscript.

Funding: The scientific research was funded by the statute subvention of the Czestochowa University of Technology, Faculty of Management and Faculty of Infrastructure and Environment.

Institutional Review Board Statement: Not applicable.

Informed Consent Statement: Not applicable.

Data Availability Statement: Not applicable. 
Conflicts of Interest: The authors declare no conflict of interest.

\section{References}

1. Merli, R.; Preziosi, M.; Ippolito, C. Promoting sustainability through EMS application: A survey examining the critical factors about EMAS registration in Italian organizations. Sustainability 2016, 8, 197. [CrossRef]

2. McWilliams, A.; Siegel, D.S.; Wright, P.M. Corporate social responsibility: Strategic implications. J. Manag. Stud. 2006, 43, 1-18. [CrossRef]

3. Rebelo, M.F.; Santos, G.; Silva, R. Integration of management systems: Towards a sustained success and development of organizations. J. Clean. Prod. 2016, 127, 96-111. [CrossRef]

4. Prajogo, D.; Tang, A.K.Y.; Lai, K.-H. The diffusion of environmental management system and its effect on environmental management practices. Int. J. Oper. Prod. Manag. 2014, 34, 565-585. [CrossRef]

5. Heras-Saizarbitoria, I.; Arana, G.; Boiral, O. Outcomes of environmental management systems: The role of motivations and firms' characteristics. Bus. Strategy Environ. 2016, 25, 545-559. [CrossRef]

6. Bielski, S.; Zielińska-Chmielewska, A.; Marks-Bielska, R. Use of environmental management systems and renewable energy sources in selected food processing enterprises in Poland. Energies 2021, 14, 3212. [CrossRef]

7. Gecevska, V.; Donev, V.; Polenakovik, R. A review of environmental tools towards sustainable development. Ann. Fac. Eng. Hunedoara Int. J. Eng. 2016, 14, 147-152.

8. Rolewicz-Kalińska, A.; Lelicińska-Serafin, K.; Manczarski, P. The circular economy and organic fraction of municipal solid waste recycling strategies. Energies 2020, 13, 4366. [CrossRef]

9. Domingues, P.; Sampaio, P.; Arezes, P.M. Management systems integration: Survey results. Int. J. Qual. Reliab. Manag. 2017, 34, 1252-1294. [CrossRef]

10. Laskurain, I.; Ibarloza, A.; Larrea, A.; Allur, E. Contribution to energy management of the main standards for environmental management systems: The case of ISO 14001 and EMAS. Energies 2017, 10, 1758. [CrossRef]

11. Włodarczyk, B.; Firoiu, D.; Ionescu, G.H.; Ghiocel, F.; Szturo, M.; Markowski, L. Assessing the sustainabledevelopment and enewable energy sources relationship in EU countries. Energies 2021, 14, 2323. [CrossRef]

12. Ćetković, J.; Lakić, S.; Živković, A.; Žarković, M.; Vujadinović, R. Economic analysis of measures for GHG emission reduction. Sustainability 2021, 13, 1712. [CrossRef]

13. Ober, J.; Karwot, J. Tap water quality: Seasonal user surveys in Poland. Energies 2021, 14, 3841. [CrossRef]

14. Ramos, H.M.; Morillo, J.G.; Diaz, J.A.R.; Carravetta, A.; McNabola, A. Sustainable water-energy nexus towards developing countries' water sector efficiency. Energies 2021, 14, 3525. [CrossRef]

15. Barón, A.; de Castro, R.; Giménez, G. Circular economy practices among industrial EMAS-registered SMEs in Spain. Sustainability 2020, 12, 9011. [CrossRef]

16. Campos, L.M.S.; De Melo-Heizen, D.A.; Verdinelli, M.A.; Cauchick-Miguel, P.A. Environmental performance indicators: A study on ISO 14001 certified companies. J. Clean. Prod. 2015, 99, 286-296. [CrossRef]

17. ISO. ISO 14001:2015 Environmental Management Systems-Requirements with Guidance for Use. 2015. Available online: https:/ / www.iso.org/standard/60857.html (accessed on 12 July 2021).

18. Regulation (EC) No 1221/2009 of the European Parliament and of the Council of 25 November 2009 on the Voluntary Participation by Organisations in a Community Eco-Management and Audit Scheme (EMAS), Repealing Regulation (EC) No 761/2001 and Commission Decisions 2001/681/EC and 2006/193/EC. Available online: https:/ / eur-lex.europa.eu/legal-content/EN/TXT/ $\mathrm{PDF} /$ ?uri=CELEX:02009R1221-20190109\&from=EN (accessed on 25 June 2021).

19. Commission Regulation (EU) 2017/1505 of 28 August 2017 Amending Annexes I, II and III to Regulation (EC) No 1221/2009 of the European Parliament and of the Council on the Voluntary Participation by Organisations in a Community Eco-Management and Audit Scheme (EMAS). Available online: https:/ / eur-lex.europa.eu/legal-content/EN/TXT/PDF/?uri=CELEX:32017R150 $5 \&$ from $=\mathrm{EN}$ (accessed on 10 June 2021).

20. Wolniak, R.; Wyszomirski, A.; Olkiewicz, M.; Olkiewicz, A. Environmental corporate social responsibility activities in heating industry-Case study. Energies 2021, 14, 1930. [CrossRef]

21. Novelli, V.; Geatti, P.; Bianco, F.; Ceccon, L.; Del Frate, S.; Badin, P. The EMAS registration of the Livenza furniture district in the province of Pordenone (Italy). Sustainability 2020, 12, 898. [CrossRef]

22. González González, A.; García-Sanz-Calcedo, J.; Rodríguez Salgado, D. Evaluation of energy consumption in German hospitals: Benchmarking in the public sector. Energies 2018, 11, 2279. [CrossRef]

23. Merli, R.; Preziosi, M.; Massa, I. EMAS regulation in Italian clusters: Investigating the involvement of local stakeholders. Sustainability 2014, 6, 4537-4557. [CrossRef]

24. Hajduk-Stelmachowicz, M. Energy management in regional directorates for environmental protection registered in the ecomanagement and audit scheme (EMAS)-selected aspects. Studia Mater. 2018, 28, 26-36. [CrossRef]

25. Szyszka, B.; Matuszak-Flejszman, A. EMAS in Poland: Performance, effectiveness, and future perspectives. Pol. J. Environ. Stud. 2017, 26, 809-817. [CrossRef]

26. Myszczyszyn, J. The environmental management systems as a opportunity in promoting sustainable development with special emphasis on the community eco-management and audit scheme (EMAS). Folia Pomeranae Univ. Technol. Stetinensis. Oeconomica 2017, 333, 63-78. [CrossRef] 
27. Heras-Saizarbitoria, I.; Arana, G.; Boiral, O. Exploring the dissemination of environmental certifications in high and low polluting industries. J. Clean. Prod. 2015, 89, 50-58. [CrossRef]

28. Ociepa-Kubicka, A. EMAS-A Tool Supporting Eco-Innovations; LAP Lambert Academic Publishing: Saarbrücken, Germany, 2015.

29. EUROSTAT. Sustainable Development in the European Union. Monitoring Report of the EU Sustainable Development Strategy; Publications Office of the European Union, EUROSTAT: Luxembourg, 2015; Volume 105.

30. European Commission. Environment. Eco-Management and Audit Scheme. Statistics \& Graphs. Available online: https: / / ec.europa.eu/environment/emas/emas_registrations/statistics_graphs_en.htm (accessed on 27 September 2020).

31. Merli, R.; Preziosi, M. The EMAS impasse: Factors influencing Italian organizations to withdraw or renew the registration. J. Clean. Prod. 2018, 172, 4532-4543. [CrossRef]

32. Merli, R.; Lucchetti, M.C.; Preziosi, M.; Arcese, G. Causes of eco-management and audit scheme (EMAS) stagnation and enabling measures to stimulate new registrations: Characterization of public administrations and private-owned organizations. J. Clean. Prod. 2018, 190, 137-148. [CrossRef]

33. Preziosi, M.; Merli, R.; D'Amico, M. Why companies do not renew their EMAS registration? An exploratory research. Sustainability 2016, 8, 191. [CrossRef]

34. European Commission. The Revised Annexes of the Emas Regulation; Publications Office of the European Union: Luxembourg, 2017. Available online: https:/ / ec.europa.eu/environment/emas/pdf/factsheets/emas_revised_annexes.pdf (accessed on 12 July 2021).

35. Cieślak, S. EMAS oraz ISO 14001. Energetyka Ciepl. i Zawodowa 2019, 1, 32-36.

36. Martins, F.; Fonseca, L. Comparison between eco-management and audit scheme and ISO 14001:2015. Energy Procedia 2018, 153, 450-454. [CrossRef]

37. Testa, F.; Rizzi, F.; Daddi, T.; Gusmerotti, N.M.; Frey, M.; Iraldo, F. EMAS and ISO 14001: The differences in effectively improving environmental performance. J. Clean. Prod. 2014, 68, 165-173. [CrossRef]

38. Skorek, A.; Włodarczyk, R. Analysis of eco-management and audit scheme (EMAS) functionality in European and Polish organizations. Rynek-Społeczeństwo-Kult. (Market.-Soc.-Cult.) 2017, 2, 6-10.

39. Tuczek, F.; Castka, P.; Wakolbinger, T. A review of management theories in the context of quality, environmental and social responsibility voluntary standards. J. Clean. Prod. 2018, 176, 399-416. [CrossRef]

40. EMAS-Factsheet EMAS and ISO 14001: Complementarities and Difference December 2011-First Edition. Available online: https: / / ec.europa.eu/environment/emas/pdf/factsheets/EMASiso14001_high.pdf (accessed on 25 June 2021).

41. FINAL REPORT. Study on the Costs and Benefits of EMAS to Registered Organisations. Study Contract No. 07.0307/2008/517800 /ETU/G.2. 2009. Available online: https:/ / ec.europa.eu/environment/emas/pdf/other/costs_and_benefits_of_emas.pdf (accessed on 10 July 2021).

42. European Commission. EMAS Promotion \& Policy Support in the Member States. In Compendium 2015; Publications Office of the European Union: Luxembourg, 2015. Available online: https://ec.europa.eu/environment/emas/pdf/other/EMAS_ Compendium_2015.pdf (accessed on 5 July 2021).

43. Biondi, V.; Frey, M.; Iraldo, F. Environmental management systems and SMEs. Motivations, opportunities and barriers related to EMAS and ISO 14001 implementation. Greener Manag. Int. 2000, 29, 55-69. [CrossRef]

44. Ferrón-Vílchez, V. Does symbolism benefit environmental and business performance in the adoption of ISO 14001? J. Environ. Manag. 2016, 183, 882-894. [CrossRef]

45. Iatridis, K.; Kesidou, E. What drives substantive versus symbolic implementation of ISO 14001 in a time of economic crisis? Insights from Greek manufacturing companies. J. Bus. Ethics 2018, 148, 859-877. [CrossRef]

46. Daddi, T.; Testa, F.; Frey, M.; Iraldo, F. Exploring the link between institutional pressures and environmental management systems effectiveness: An empirical study. J. Environ. Manag. 2016, 183, 647-656. [CrossRef]

47. Waxin, M.-F.; Knuteson, S.L.; Bartholomew, A. Drivers and challenges for implementing ISO 14001 environmental management systems in an emerging Gulf Arab country. Environ. Manag. 2019, 63, 495-506. [CrossRef]

48. Neugebauer, F. EMAS and ISO 14001 in the German industry-Complements or substitutes? J. Clean. Prod. 2012, 37, 249-256. [CrossRef]

49. Morrow, D.; Rondinelli, D. Adopting corporate environmental management systems: Motivations and results of ISO 14001 and EMAS certification. Eur. Manag. J. 2002, 20, 159-171. [CrossRef]

50. Seifert, C. The Barriers for voluntary environmental management systems-The case of EMAS in hospitals. Sustainability 2018, 10, 1420. [CrossRef]

51. Murmura, F.; Liberatore, L.; Bravi, L.; Casolani, N. Evaluation of Italian companies' perception about ISO 14001 and eco management and audit scheme III: Motivations, benefits and barriers. J. Clean. Prod. 2018, 174, 691-700. [CrossRef]

52. Heras-Saizarbitoria, I.; Dogui, K.; Boiral, O. Shedding light on ISO 14001 certification audits. J. Clean. Prod. 2013, 51, 88-98. [CrossRef]

53. Carrillo-Labella, R.; Fort, F.; Parras-Rosa, M. Motives, barriers, and expected benefits of ISO 14001 in the agri-food sector. Sustainability 2020, 12, 1724. [CrossRef]

54. Nibusiness Info.CO.UK. Set Up An Environmental Management System (EMS). Advantages and Disadvantages of Environmental Management Systems (EMS). Available online: https:/ / www.nibusinessinfo.co.uk/content/advantages-and-disadvantagesenvironmental-management-systems-ems (accessed on 24 June 2021). 
55. Ikram, M.; Zhou, P.; Shah, S.A.A.; Liu, G.Q. Do environmental management systems help improve corporate sustainable development? Evidence from manufacturing companies in Pakistan. J. Clean. Prod. 2019, 226, 628-641. [CrossRef]

56. Testa, F.; Iraldo, F.; Daddi, T. The Effectiveness of EMAS as a management tool: A key role for the internalization of environmental practices. Organ. Environ. 2018, 31, 48-69. [CrossRef]

57. Díaz de Junguitu, A.; Allur, E. The adoption of environmental management systems based on ISO 14001, EMAS, and alternative models for SMEs: A qualitative empirical study. Sustainability 2019, 11, 7015. [CrossRef]

58. Riaz, H.; Saeed, A. Impact of environmental policy on firm's market performance: The case of ISO 14001. Corp. Soc. Responsib. Environ. Manag. 2020, 27, 681-693. [CrossRef]

59. Martín-Peña, M.L.; Díaz-Garrido, E.; Sánchez-López, J.M. Analysis of benefits and difficulties associated with firms' environmental management systems: The case of the Spanish automotive industry. J. Clean. Prod. 2014, 70, 220-230. [CrossRef]

60. Jaźwińska, D. The benefits and costs of implementation of eco-management and audit scheme (EMAS). Sci. J. Pozn. Univ. Technol. Organ. Manag. 2013, 61, 49-60.

61. Reis, A.V.; Neves, F.O.; Hikichi, S.E.; Salgado, E.G.; Beijo, L.A. Is ISO 14001 certification really good to the company? A critical analysis. Production 2018, 28, e20180073. [CrossRef]

62. Kadasah, N.A. 2013. Attitudes of managers towards the potential effects of ISO 14001 in Saudi Arabia: Factor analysis. Int. Bus. Res. 2013, 6, 91-101. [CrossRef]

63. Zobel, T. ISO 14001 certification in manufacturing firms: A tool for those in need or an indication of greenness? J. Clean. Prod. 2013, 43, 37-44. [CrossRef]

64. Majerník, M.; Daneshjo, N.; Chovancová, J.; Sančiová, G. Design of integrated management systems according to the revised ISO standards. Pol. J. Manag. Stud. 2017, 15, 135-143. [CrossRef]

65. Álvarez-García, J.; Del RíoRama, M.D.L.C. Sustainability and EMAS: Impact of motivations and barriers on the perceived benefits from the adoption of standards. Sustainability 2016, 8, 1057. [CrossRef]

66. Heras-Saizarbitoria, I.; Boiral, O.; Arana, G. Renewing environmental certification in times of crisis. J. Clean. Prod. 2016, 115, 214-223. [CrossRef]

67. Boiral, O.; Guillaumie, L.; Heras-Saizarbitoria, I.; Tayo Tene, C.V. Adoption and outcomes of ISO 14001: A systematic review. Int. J. Manag. Rev. 2018, 20,411-432. [CrossRef]

68. Pachura, P.; Ociepa-Kubicka, A. Eco-management and audit scheme (EMAS) functioning on the example of the water supply and sewerage joint stock company of the Częstochowa district. Pol. J. Manag. Stud. 2014, 10, 143-150. 